\title{
Türk ve Singapur Matematik Ders Kitaplarında Problem Analizi:
} Kesirlerle Bölme İşlemi

\author{
Problem Analysis in Turkish and Singapore Mathematics Textbooks: \\ Division of Fraction \\ Suphi Önder BÜTÜNER*
}

• Geliş Tarihi: 05.02.2019• Kabul Tarihi: 09.04.2019• Yayın Tarihi: 21.06.2019

\section{$\ddot{\mathbf{O} z}$}

Bu çalışmada Türk ve Singapur matematik ders kitabı kesirlerle bölme işlemi konusunda yer verilen problemler açısından karşılaştırılmalı olarak incelenmiştir. Çalışmada ikişer adet Türk ve Singapur matematik ders kitabı analiz edilmiştir. Kitaplarda yer alan problemler; adım sayısı, cevap tipi, bağlam ve bilişsel beklenti özellikleri açısından sınıflandırılmışlardır. Analizler iki farklı araştırmacı tarafından yapılmış; araştırmacılar arasındaki Cohen Kappa uyum indeksi her bir kategori için 0.98-1.00 arasında bulunmuştur. Elde edilen bulgulara göre, Singapur kitabında, Türk kitaplarına kıyasla çok adımlı, açıklama-çözüm gerektiren problem sayısı daha fazladır. Her iki ülke kitabındaki kesirlerle bölme ile ilgili tüm problemler yeterli veri içermektedir. Her iki ülkenin ders kitaplarındaki gerçek hayat problemi sayısı azdır. Ayrıca Singapur ders kitabı, çoklu formda ifade edilmiş problemler bakımından Türk kitaplarından zengindir. Türk kitaplarında, Singapur kitabına kıyasla matematiksel muhakeme ve temsil kategorisine giren problem sayısı oldukça az olup, Türk kitaplarında kavramsal bilgi kategorisine giren hiçbir problem bulunmamaktadır. Elde edilen bulgular, Singapur'un uluslararası sınavlarda sayılar öğrenme alanı özelinde, Türkiye'den daha iyi bir performans göstermesinin nedenlerinden biri olarak düşünülebilir. Bu çalışmanın devamında, matematik öğretmenlerinin ders kitaplarındaki problemlerden ne ölçüde yararlandıkları ve derslerinde ne tip problemlere yer verdikleri araştırllabilir.

Anahtar sözcükler: kesirlerle bölme işlemi, matematik ders kitabı, problem, Singapur, Türkiye

Atıf:

Bütüner, S.Ö. (2019). Türk ve Singapur matematik ders kitaplarında problem analizi: Kesirlerle bölme işlemi. Pamukkale Üniversitesi Ĕ̌itim Fakültesi Dergisi, 47, 370-394. doi:10.9779/pauefd.522909

\footnotetext{
* Dr. Öğr. Üyesi, Yozgat Bozok Üniversitesi, Matematik ve Fen Bilimleri Eğitimi Bölümü, Yozgat. ORCIDD: 00000001-7083-6549, s.onder.butuner@bozok.edu.tr; onderbutuner@mynet.com
} 


\begin{abstract}
In this study, Turkish and Singapore mathematics textbooks were compared in terms of the problems included in the subject of division of fractions. The problems in textbooks were categorized in terms of the number of steps, type of answer, context and cognitive expectation characteristics. The analyses were conducted by two different researchers, and the Cohen Kappa agreement index between the researchers was found between $0.98-1.00$ for each category. According to the findings, the Singapore book has more steps and more problems requiring explanation-solution compared to the Turkish books. All problems related to dividing fractions in both countries' books contain sufficient data. The number of daily life problems in the textbooks is small. In addition, it was determined that the Singapore textbook was richer than the Turkish books in terms of problems expressed in a combined form. In the Turkish books, there are few problems in the category of mathematical reasoning and representation compared to the Singapore book, and there is no problem in the Turkish books in the category of conceptual knowledge. The findings can be considered as one of the reasons why Singaporean students perform better than Turkish students in terms of number content domain in international exams. In future studies, it can be investigated what kind of problems mathematics teachers use in their lessons.
\end{abstract}

Keywords: dividing fractions, mathematics textbook, problem, Singapore, Turkey

\title{
Cited:
}

Bütüner, S.Ö. (2019). Problem analysis in Turkish and Singapore mathematics textbooks: Division of fraction. Pamukkale Üniversitesi Eğitim Fakültesi Dergisi, 47, 370-394.

doi: 10.9779/pauefd.522909 


\section{Giriș}

Uluslararası karşılaştırma çalışmaları (TIMSS, PISA) ülkelerin matematik başarılarını ortaya koyan önemli göstergelerden biridir. Uzak doğu ülkelerinin bu sinavlarda ilk siralarda yer aldıkları bilinmektedir (Zhu ve Fan, 2006). Singapur 2015 yılında yapılan Uluslararas1 matematik ve fen eğilimleri araştırmasında (TIMSS) sayılar öğrenme alanında, 629 puanla 1. sırada yer almıştır. Türkiye ise sayılar öğrenme alanında 447 puanla düşük bir performans gösterebilmiştir (Mullis, Martin, Foy ve Hooper, 2015). Türk ve Singapurlu öğrencilerin sayılar öğrenme alanındaki performansları arasındaki farklılı̆̆ birçok nedenle açıklamak mümkündür. Öğretmenlerin derslerinde ana kaynak olarak kullandıkları ders kitapları, öğrencilerin matematik performansları arasındaki farklılı̆̆ın nedenlerinden biri olarak düşünülebilir. Çünkü bir ülkede kullanılan ders kitapları o ülkenin eğitim felsefesini yansıtmakta, öğrencilerin ne öğreneceklerini, nasıl öğreneceklerini ve öğretmenlerin ne öğreteceklerini belirlemektedir (Son ve Senk, 2010; Stein, Remillard ve Smith, 2007).

Son yıllarda kitap karşılaştırma çalışmalarının sayısındaki artış dikkat çekmektedir. Yapılan karşılaştırma çalışmalarında, büyük ölçüde uluslararası sınavlarda ilk sıralarda yer alan Çin, Kore, Japonya, Tayvan, Singapur, Finlandiya gibi ülkelerin ders kitapları kullanılmıştır (bkz, Tablo 1). Yapılan çalışmalarda kitaplar, öğretim içeriği veya problem tipi açısından karşılaştırılmışlardır (Hong ve Choi, 2014). Bu çalışmada, Türk ve Singapur matematik ders kitapları, kesirlerle bölme işlemi konusunda yer verilen problem tipleri açısından karşılaştırmalı olarak incelenmiştir. Bir sonraki kısımda çalışmada neden Singapur kitaplarının tercih edildiği ve karşılaştırma çalışmasının kesirlerle bölme işlemi konusunda yapıldığı gerekçelendirilmiştir.

\section{Neden Singapur Ders Kitapları?}

Bu karşılaştırma çalışmasında Singapur ders kitaplarının seçilme nedenlerinden ilki, Türkiye'de kullanılan matematik ders kitaplarının, uluslararası sınavlarda ilk beş içerisinde yer alan ülkelerin kitaplarıyla (sadece Singapur kitapları) tasarım özellikleri açısından (Erbaş, Alacacı ve Bulut, 2012) ve problem tipi açısından (Özer ve Sezer, 2014) karşılaştırılmış olmasıdır. Özer ve Sezer'in (2014) çalışmalarında sadece 8. sınıf Türk ders kitabında yer alan konular üzerinden bir karş1laştırma gerçekleştirilmiştir. Diğer neden ise, Singapur'da ilkokuldan üniversiteye kadar problem çözmeyi merkeze alan bir matematik müfredat çerçevesinin kullanılıyor olmasıdır. Bu çerçeveye göre, birbiriyle ilişkili beş bileşen öğrencilerin problem çözme becerilerinin gelişimine katkı sağlamaktadır. Bu bileşenler: kavramlar, beceriler, süreçler, üst biliş ve tutumlar olarak siralanabilir (Dindyal, 2006; Wong ve Lee, 2009). Singapur matematik müfredatı, kavramsal öğrenmeyi ön plana almaktadır. Bu açıdan Singapur matematik müfredatı, öğrencilere bir matematiksel kavramı veya kuralı derinlemesine öğrenip öğrenmediklerini yoklayan soruların sorulmasını teşvik etmektedir. Singapur matematik müfredat çerçevesindeki matematiksel süreçler; muhakeme, iletişim, ilişkilendirme ve modelleme gibi süreç becerilerini içerir. Singapur müfredat çerçevesinde, öğrencilerde bu becerilerin harekete geçirilebilmesi için öğrencilerin gerçek hayat problemleriyle ve açık uçlu problemlerle karşı karşıya gelmeleri gerektiğine, öğrencilerin bilişüstü farkındalık düzeyinin gelişimi için, öğrencilerin açık uçlu problemler üzerinden yaptıkları çözümleri tartışmalarına firsatlar sunmanın önemine temas edilmiştir (Foong, 2009; Ibrahim ve Othman, 2010; MOES, 2012). Singapur Matematik eğitiminin bir diğer önemli özelliği de Amerikalı psikolog Jerome Bruner'in çalışmalarını baz alan üç basamaklı öğrenme sürecinin (somut-görsel-soyut) benimsenmiş olmasıdır. Üç 
basamaklı öğrenme süreci, öğrencileri farklı temsilleri kullanma ve temsiller arası geçiş yapma konusunda teşvik etmektedir. Farklı temsil biçimlerinin varlığı, öğrencilerin bilgiyi nasıl göstereceklerini öğrenmesi ve bir temsilden diğerine geçiş için çok önemlidir (Kaput, 1987). Singapur öğretim programında aritmetik ve cebir problemlerinin çözümünde kullanılan "model yöntemi”; öğrencilerin sözel formda verilmiş bir aritmetik veya cebir problemini görsel formda ifade ederek çözmeye, ardından problemin çözümünü sembolik formda yapmaya itmektedir (Fong ve Lee, 2009). Dolayısıyla Singapur matematik müfredatında, öğretmenlerden günlük deneyimlerden ve anlamlı bağlamlardan yola çıkarak, öğrencilerini somut ve resimsel gösterimleri kullanmaları konusunda teşvik etmeleri ve soyut matematiksel kavramları anlamlı şekilde öğrenmelerinde onlara yol gösterici olmaları beklenmektedir (MOES, 2012). Özetle, Singapur matematik müfredat çerçevesinde; çok adımlı, açıklama veya çözüm gerektiren gerçek hayat problemlerinin kullanımının önemine işaret edilmektedir. Bunun yanında, öğrencilerin süreç becerilerinin ve bilişüstü farkındalık düzeyinin gelişimini tetikleyici sorulara yer verilmesi gerektiği vurgulanmaktadır.

\section{Neden Kesirlerle Bölme İşlemi?}

Kesirlerle bölme işlemi konusunun etkili şekilde öğretimi, oran, yüzde, eğim, ondalık gösterim gibi kavramların anlaşılabilmesi için gereklidir (Son, 2011). Kesirlerle bölme işlemi, cebir öğrenme alanıyla (Brown ve Quinn 2007; Siegler vd, 2010) ve kesirle çarpma ve kesirlerle çıkarma işlemi ile yakından ilişkilidir (Van de Walle vd, 2010). Kesirlerle çarpma işlemi ile ilişkilidir çünkü kesirle bölme işlemi problemlerinin çözümünde ters çevir çarp algoritmas1 yaygın olarak kullanılmaktadır. Kesirlerle çıkarma işlemi ile ilişkilidir çünkü kesirlerle bölme problemlerinin anlamlarından biri ölçme-tekrarlı çıkarmadır. Bir çok matematiksel kavramla ilişkili olan kesirlerle bölme konusunda öğrencilerin hatta öğretmenlerin bir takım zorluklar yaşadıkları bilinmektedir (Carpenter vd, 1988; Leung ve Carbone, 2013; Simon, 1993; Tirosh, 2000; Isıksal ve Çakıroğlu, 2008). Öğrenciler, sıklıkla eşit paylaşım problemleriyle karşı karşıya kaldıklarında, bölenin bir tamsayı olması gerektiği, bölenin ve bölümün, bölünenden küçük olması gerektiği düşüncesine kapılmaktadırlar. Öğrencilerin, bölme işleminin sonucunun daima küçük olması gerektiği yönündeki kavram yanılgıları, ilköğretim yıllarının başlarında doğal sayılar kümesinin elemanları ile işlem yapmalarından kaynaklanmaktadır (Tirosh, 2000). Matematik öğretiminde, matematiksel kavramların birbiriyle ilişkilendirilmesi (Örneğin, kesirondalık gösterim-yüzde veya çarpma-bölme işlemi vb.) ve bir matematiksel kuralın veya algoritmanın neyi ifade ettiğinin ve nasıl ortaya çıktığının açıklanması önemlidir. Çünkü öğrenciler anlamadıkları bir prosedürü takip ettiklerinde elde ettikleri sonuçların anlamlı olup olmadıklarını sağliklı şekilde değerlendirememektedirler. Altında yatan anlam, anlaşılamamış olan algoritmaların birbirlerine karıştırılma olasılığı yüksektir (Van De Walle vd, 2010).

Nitekim bazı lise öğrencileri bile $\frac{a}{b}+\frac{c}{d}=\frac{a+c}{b+d}$ ve $\frac{a}{b} \div \frac{c}{d}=\frac{(a d \div b c]}{b d}$ türünden hatalar yapabilmektedirler ( $\mathrm{Li} \mathrm{vd,} \mathrm{2009).} \mathrm{Bu} \mathrm{yüzden} \mathrm{ders} \mathrm{kitaplarında,} \mathrm{öğrencilerin} \mathrm{çözüm}$ algoritmalarının (ters çevir çarp, ortak payda) anlamlarını, kavramsal olarak öğrenip öğrenmediklerini belirlemeye dönük problemlere yer verilmesi önemlidir. Çünkü öğretim biçimi ile ölçme ve değerlendirme uygulamaları arasında sıkı bir ilişki vardır (Black ve Wiliam, 1998). Scouller (1998) ve Tang (1992) hatırlama ve ezberleme gibi düşük zihinsel süreç becerilerini yoklayan sorularla değerlendirilecek öğrencilerin, yüzeysel öğrenme yaklaşımlarını 
benimsediklerini ifade etmişlerdir. Bu görüşe paralel olarak $\frac{4}{9} x \frac{1}{3}=? \frac{4}{9} \div \frac{1}{3}=$ ? şeklindeki, sadece sayısal cevap ve sayısal ifade gerektiren soruları çözmek için öğrencilerin ilgili prosedürü hatırlamaları yeterli olacaktır. Öğretim biçimi ile ölçme ve değerlendirme uygulamaları arasında sıkı bir ilişkinin olduğu düşünüldüğünde, Türk ve Singapur kitaplarının kesirlerle bölme işlemi konusunda yer alan problemler açısından karşılaştırılarak, problem tiplerinin dağılımının tespit edilmesi, kesirlerle bölme işleminin nasıl öğretildiği ile ilgili fikir verebilir.

Çalışmanın önemini ortaya koyan diğer durum, Türk ve Singapur matematik ders kitaplarının, kesirle çarpma ve kesirlerle çıkarma işlemi ile ilişkili olan kesirlerle bölme işlemi konusunda yer verilen problem tipleri açısından karşılaştırılmasının, Türk ve Singapurlu öğrencilerin sayılar öğrenme alanındaki başarı durumu hakkında fikir verebilecek olmasıdır. Uluslararası matematik ve fen eğilimleri araştırmasında (TIMSS); bilme, uygulama ve muhakeme bilişsel alanlarından sorular sorulmaktadır. Soruların üçte ikisi uygulama ve muhakeme düzeyindedir. Öğrencilerin, kesirlerle bölme işlemi ile ilgili uygulama düzeyindeki soruları çözebilmeleri için, kesirlerle bölme işlemi içerisinde yer alan stratejilerin ve algoritmaların anlamlarını ve neden kullandıklarını bilmeleri gerekmektedir. Aynı araştırmada (TIMSS), öğrencilere muhakeme düzeyinde açık uçlu ve çok adımlı sorular sorulmaktadır. Muhakeme düzeyindeki sorularda, öğrencilerden yaptıkları çözümü açıklamaları ve farklı çözüm stratejileri kullanmaları beklenir ve yapılan doğru çözüm iki puan olarak değerlendirilir (Mullis vd, 2015). Dolayısıyla, Türk ve Singapur kitaplarında kesirlerle bölme işlemi konusunda, bilme, uygulama ve muhakeme düzeyindeki problem sayılarının dağılımının tespit edilmesi, Türk ve Singapurlu öğrencilerin sayılar öğrenme alanı özelinde başarı durumları ile ilgili çıkarımlarda bulunmamıza yardımcı olabilir. Ayrıca çalışmadan elde edilen sonuçlar ışığında, müfredat hazırlayıcılara ders kitaplarının iyileştirilmesi konusunda çeşitli öneriler sunulabilir.

\section{Yapılmış Çalışmalar}

Literatürde ders kitaplarının kesirler konusu içerisinde yer alan problemler açısından karşılaştırıldığ1 çeşitli araştırmalara rastlanmaktadır (Alejmi, 2012; Kar vd, 2018; Li vd, 2009; Özer ve Sezer, 2014; Son ve Senk, 2010; Vula vd, 2015; Yang vd, 2010; Yang, 2018). Kitap karşılaştırma çalışmalarında, hangi ülkelerin ders kitaplarının karşılaştırıldığı, karşılaştırma yapılan konuların neler olduğu Tablo 1'de sunulmuştur. Ayrıca Türkiye'de kullanılan matematik ders kitaplarının hangi ülkelerin ders kitaplarıyla, hangi açılardan karşılaştırılmasının yapıldığı Tablo 1'de sunulmuştur.

Tablo 1'de görüldüğü üzere, Li vd. (2009) ve Son ve Senk (2010) ise kesirlerle bölme işlemi konusu üzerinde kitap karşılaştırma çalışması yapmışlardır. Son ve Senk (2010), Kore ve Amerika ders kitaplardaki problemlerin çoğunun tek adımlı olduğunu ve sadece sayısal cevap gerektirdiğini ve işlemsel anlamayı ölçtüğünü tespit etmişlerdir. Ayrıca Kore kitaplarındaki problemlerin \%18'i çok adımlı hesaplama becerisi gerektirirken, Amerika kitaplarında bu yüzde sadece \%1'dir. Sayısal ifade, çözüm ve açıklama gerektiren, muhakeme becerisini yoklayan soru sayısı, Kore kitaplarında Amerika kitaplarına kıyasla daha fazla bulunmuştur. Her iki kitapta da görsel ve sözel problemler, tüm problemlerin yaklaşık \%30'unu oluşturmaktadır. Ayrıca Amerika ve Kore kitaplarında yer alan problemlerin çoğu gerçek hayat problemi değildir. Li vd. (2009), Amerika ders kitaplarında hesaplama gerektiren problemlerin tek 
adımda yapılacak tarzda olduğunu, tersine Çin ve Japon ders kitaplarında daha karmaşık yapıda hesap içeren problemler bulunduğunu ifade etmişlerdir. Özer ve Sezer (2014), yaptıkları çalışmada Türk ders kitaplarında yer alan sekizinci sınıf matematik konularını dikkate alarak, Türk, Amerika ve Singapur ders kitaplarında bu konular içerisinde yer alan problemleri karşılaştırmışlardır. Çalışmanın sonucunda Türk kitaplarında, çok adımlı çözüm gerektiren problem sayısı, Amerika ve Singapur kitaplarına kıyasla daha az bulunmuştur. Ancak kavramsal bilgi kategorisinde yer alan problem sayısının, belirgin bir şekilde Amerika ve Singapur ders kitaplarından fazla olduğu tespit edilmiştir. Ayrıca Türk kitaplarında problem çözme kategorisinde yer alan soru sayısı diğer iki ülkeye göre yüksek olmasına rağmen Türk kitaplarındaki soru sayısı diğer iki ülkeye göre azdır.

Tablo 1. Ders Kitaplarının Kesirler Konusunda Yer Verilen Problemler Açısından Karşılaştırıldığı Çalışmaların Genel Görüntüsü

\begin{tabular}{|c|c|c|c|}
\hline Yazarlar & Y11 & Ülkeler & Konu \\
\hline Li vd. & 2009 & Amerika, Çin, Japonya & Kesirlerle Bölme \\
\hline Yang vd. & 2010 & Amerika, Tayvan, Singapur & \\
\hline Charalambous vd.. & 2010 & Tayvan, İrlanda, Kıbrıs & $\begin{array}{l}\text { Kesirlerle Toplama } \\
\text { ve Çıkarma }\end{array}$ \\
\hline Son ve Senk & 2010 & Amerika ve Kore & $\begin{array}{l}\text { Kesirlerle Çarpma ve } \\
\text { Bölme }\end{array}$ \\
\hline Alejmi & 2012 & Amerika, Japonya, Kuveyt & $\begin{array}{l}\text { Kesirlerle Toplama } \\
\text { ve Çıkarma }\end{array}$ \\
\hline Son & 2012 & Amerika, Kore & $\begin{array}{l}\text { Kesirlerle Toplama } \\
\text { ve Çıkarma }\end{array}$ \\
\hline \multirow[t]{2}{*}{ Özer ve Sezer } & 2014 & Amerika, Singapur, Türkiye & $\begin{array}{l}\text { 8.sinif matematik } \\
\text { ders }\end{array}$ \\
\hline & & & $\begin{array}{l}\text { kitabinda yer alan } \\
\text { problemler }\end{array}$ \\
\hline Vula vd. & 2015 & Kosova, Arnavutluk & Kesirler \\
\hline Yang & 2018 & Tayvan, Finlandiya & Kesirler \\
\hline Kar vd. & 2018 & Amerika, Türkiye & Kesirlerle Çarpma \\
\hline
\end{tabular}

Yang vd. (2010) çalışmalarının sonucunda, Amerika ders kitaplarındaki problemlerin \%90'ından fazlasının gerçek hayat problemi olduğunu tespit etmiştir. Singapur ders kitaplarında kesir ve yüzde konusu için problemlerin yaklaşık \%35'i, Tayvan kitaplarında ise yaklaşık \%50'si gerçek hayat problemleridir. Çalışmanın sonucunda ortaya çıkan diğer sonuca göre, Amerika ders kitaplarında yer alan problemlerin çoğu, kavramsal anlamayı ölçmeyi, Tayvan ve Singapur kitaplarında yer alan problemlerin çoğu işlemsel akıcıllı̆g ölçmeyi hedeflemektedir. Alejmi'nin (2012) çalışması, Japon kitaplarında kesirlere gerçek hayat bağlamı kullanılarak giriş yapıldığını ve problemlerin çoğunun sembolik formda sunulduğunu ortaya koymaktadır. Kitaplar arasında Amerika kitapları, en az sayıda sadece sembolik formda problem içermektedir. Japon kitaplarında gerçek hayat problemlerine rastlanmamaktadır. Üç kitap (Amerika, Japonya, Kuveyt) arasında en fazla gerçek hayat problemleri Amerika ders kitabında yer almaktadır. Kuveyt kitabında ise dördüncü sınıfa kadar gerçek hayat problemi yer almamaktadır. Kuveyt kitabındaki problemler ağırlıklı olarak sembolik ve görsel formdadır. Her üç kitapta da problemlerin çoğunun hesaplama yöntemi açısından kağıt-kalem hesabına dayandığı söylenebilir. Amerika ve Kuveyt kitaplarında az oranda tahmin problemleri, Sadece Amerika kitaplarında zihinsel işlem ve hesap makinesinin kullanımını gerektiren az sayıda 
problem olduğu söylenebilir. Kuveyt ve Japon kitaplarında sözel probleme rastlanmazken, Amerika kitaplarında problemlerin yaklaşık \%15'i sözel formdadır. Yang'ın (2018), çalışmasının sonucunda Finlandiya matematik kitabında problemlerin ağırlıklı olarak (\%50'den fazla) sembolik formda sorulduğu, Tayvan kitaplarında ise çeşitli temsil biçimlerinin kullanıldığı tespit edilmiştir. Finlandiya kitaplarındaki problemler çoğunlukla gerçek hayatla ilgili olmayan problemlerken, Tayvan kitaplarındaki problemlerin yarısından fazlası gerçek hayatla ilgili problemlerdir. Kesrin temel tanımı ile ilgili Tayvan kitabındaki problemlerin dörtte üçü gerçek hayatla ilgili iken, Finlandiya kitaplarında problemlerin ancak dörtte biri gerçek hayatla ilgilidir. Ancak bu gerçek hayat problemlerinin gerçekçiliği noktasında Finlandiya kitabında yer alan problemlerin, Tayvan kitabına göre gerçek hayatla daha fazla örtüştüğü tespit edilmiştir. Görsel soruların çeşitliliği, kesrin tanımlanmasının yanında çizim gerektiren soruların bulunması ve görsellerin kullanıldığı gerçek hayat problemlerinin varlığı bakımından Finlandiya kitabı öne çıkarken, problem çözme sürecinin detaylı bir şekilde adım adım açıklanması bakımından Tayvan kitabı öne çıkmaktadır. Kar vd. (2018), çalı̧̧malarında Amerika kitaplarındaki problem sayısının, Türk kitaplarındaki problem sayısının yaklaşık üç katı olduğunu tespit etmişlerdir. Tüm kitaplardaki problemlerin yarısından fazlasının tek adımlı çözüm gerektirdiği, sadece sayısal cevaplı olduğu, gerçek hayatla ilgisinin olmadığı tespit edilmiştir. Açıklama ve çözüm gerektiren problem sayısının belirgin bir şekilde Amerika kitaplarında fazla olduğu saptanmıştır. Tüm kitaplarda problemlerin çoğu işlemsel bilgi düzeyini ölçer nitelikte olup, Amerika kitaplarından birinde kavramsal bilgi düzeyini ölçen problem sayısı diğer kitaplara oranla belirgin düzeyde fazla bulunmuştur. Matematiksel muhakeme becerisini yoklayan problem sayısı Amerika kitaplarının tümünde Türk kitaplarına oranla fazladır. Sonuç olarak, Amerika ders kitaplarında çok adımlı açıklama ve çözüm gerektiren, öğrencilerin kavramsal anlamalarını ve muhakeme becerilerini yoklayan problem sayısının Türk kitaplarına kıyasla fazla olduğu tespit edilmiştir. Problem ortaya atmayı gerektiren problem tipi, Türk kitaplarında Amerika kitaplarına göre belirgin düzeyde fazladır.

Tablo 1'de görüldüğü üzere, literatürde Türk matematik ders kitaplarının uluslararası sınavlarda ilk sıralarda yer alan uzak doğu ülkeleri ile kesirlerle bölme işlemi konusu açısından karşılaştırılmasının yapıldığı herhangi bir çalışma yer almamaktadır. Bu çalışmada, Türk ve Singapur ders kitapları, çoğu öğrencinin anlamakta zorlandığı kesirlerle bölme işlemi konusu içerisinde yer alan problem tipleri açısından karşılaştırılmıştır. Yapılan çalışma, Türk öğrencilerin uluslararası sınavlarda, matematik alanında düşük bir performans göstermesinin olası nedenleri hakkında okuyuculara fikir verebilir. Bunun yanında çalışmanın bulguları doğrultusunda, Türk ve Singapur Eğitim Bakanlığı bünyesinde çalışan öğretim programı hazırlayıcılarına, matematik ders kitaplarının içeriğinin zenginleştirilmesine dönük çeşitli öneriler sunulabilecektir. Çalışmanın problemleri aşağıda ifade edilmiştir.

- Cevap tipi, adım sayısı ve bağlam özellikleri açısından, Türk ve Singapur ders kitaplarında kesirlerle bölme işlemi konusu içerisinde yer alan problemlerin dağılımı nasıldır?

- Bilişsel beklenti özelliği açısından, Türk ve Singapur ders kitaplarında kesirlerle bölme işlemi konusu içerisinde yer alan problemlerin dağılımı nasıldır? 


\section{Yöntem}

Bu kısımda çalışmada kullanılan ders kitaplarından, problem analizinin teorik çerçevesinden ve çalışmanın geçerlik güvenirliğinden bahsedilmiştir.

\section{Çalışmada Kullanılan Ders Kitapları}

Türkiye'deki ortaokullarda hangi kitapların kullanılacağı Milli Eğitim Bakanlığı'nın kontrolü altındadır. Türkiye'de öğretmenler Milli Eğitim Bakanlığı'nca okullara gönderilen ders kitaplarını kullanmaktadırlar. Nitekim, Milli Eğitim Bakanlığ 1 öğretmen ve öğrencilere dağıtımı yapılan ders kitapları ve eğitim materyalleri dışında "yardımcı kaynak", "test kitabı", "tatil kitabı" gibi adlar altında diğer yayın ve materyallerin kullanılmaması konusunda öğretmenleri uyarmıştır. Bu açıdan Türkiye'de derslerde kullanılan temel kaynak Milli Eğitim Bakanlığ bünyesinde ve kontrolünde çıkarılan ders kitaplarıdır. Bu çalışmada ilk baskısı 2016 yılında Milli Eğitim Yayınevi'nden çıkan 6. sınıf matematik ders kitabı ile Güven (2014) tarafından yazılan 6. sınıf matematik ders kitabı incelenmiştir. Ders kitapları çalışma içerisinde TB1 ve TB2 kodları ile verilmiştir. Bu kitaplar, Türk ortaokullarında 2017-2018 eğitim öğretim yılında ve önceki yıllarda kullanılmıştır.

Singapur eğitim sisteminde, İlköğretim, 1. ve 4. sinıflar arasındaki 4 yıllık "Temel Evre" (Foundation Stage) ve İlköğretim 5. ve 6. sinıfları kapsayan 2 yıllık "Yönlendirme Evresi'nden (Orientation Stage) oluşmaktadır. İlköğretimin genel amacı öğrencilere iyi bir İngilizce, anadil ve matematik eğitimi vermektir. Singapur'da ilköğretim kademesinde şu anda dört adet matematik kitabı kullanılmaktadır. Bu kitaplar; "My pals are here!", "New Syllabus Primary Mathematics", "Shaping Maths", "Targeting Mathematics" isimli kitaplardır. Singapur ortaokullarının yaklaşık \%60'ında "My pals are here!" isimli kitap kullanılmaktadır (Yang vd, 2010, s.119). Bu kitap ilk kez 2001 yılında basılmış olup, bilişsel gelişim teorileri, üstbiliş teorileri ve yapılandırmacılık esas alınarak içerik oluşturulmuştur (Yang vd, 2010). Bu çalışmada "My pals are here!” isimli iki adet kitabın 2018 yılında çıkan üçüncü baskısı kesirlerle bölme işlemi konusu açısından incelenmiştir. Singapur'da kesirlerle bölme işlemi konusunun öğretimi iki yıla yayıldığından "My pals are here!" (5A) ve "My pals are here!" (6A) analize dahil edilmiştir. My Pals are Here! (5A)'da kesirlerle bölme işlemi ile ilgili olarak,

sözel-gerçek hayat problemlerinden yararlanılarak sadece $\mathbf{3} \div \mathbf{5}$ tipindeki ifadelerin kesir olarak yazılışı üzerinde durulmuştur. Bu açıdan çalışma içerisinde Singapur ders kitabı MP kodu ile verilmiştir. Her iki ülkenin matematik ders kitapları Eğitim Bakanlığı onayından geçirilerek okullarda kullanılan ders kitaplarıdır. Çalışma kapsamında incelenen kitaplar Tablo 2'de verilmiştir.

Tablo 2. Çalışmada Kullanılan Türk ve Singapur Matematik Ders Kitapları

\begin{tabular}{cc}
\hline Country & \multicolumn{1}{c}{ Selected Textbooks } \\
\hline Singapur & Kheong, F. H., Soon, G. K., Ramakrishnan, C. (2018). My Pals are Here Maths \\
& 6A (Pupil's Book), Mashall Cavendish Education: Singapore. \\
& Kheong, F. H., Soon, G. K., Ramakrishnan, C. (2018). My Pals are Here Maths \\
& 5A (Pupil's Book), Mashall Cavendish Education: Singapore. \\
Türkiye & Komisyon (2016). Ortaokul Matematik 6. Sinıf. Devlet Kitapları: Ankara. \\
& Güven. D. (2014). Ortaokul Matematik 6. Mega Yayncilik: Ankara. \\
\hline
\end{tabular}




\section{Problem Analizinde Kullanılan Teorik Çerçeve}

Matematik ders kitaplarında yer alan problemlerin analizinde kullanılacak teorik çerçeve oluşturulmadan önce bu konuda literatürde yapılmış çalışmalar incelenmiştir. Problem analizinde kullanılacak özellikler ve her bir özelliğin kategorileri Tablo 3'de verilmiştir. Stigler vd. (1986), Fan ve Zhu (2000), Zhu ve Fan (2006), Güven vd. (2016) problem analizinde bilişsel beklenti özelliğini kullanmamışlardır. Örneğin, Fan ve Zhu (2000), Zhu ve Fan (2006) çalışmalarında problemleri yedi kategoriye ayırarak sınıflandırmışlardır. Yazarlar, bu kategorileri; rutin-rutin olmayan, geleneksel-geleneksel olmayan, açık-kapalı uçlu, gerçek hayatla ilgili olan/olmayan, tek adımla çözülen-çok adımla çözülen, yeterli-fazla veya eksik veri içeren, matematiksel-sözel-görsel-karma formda olan problemler şeklinde ifade etmişlerdir. Güven vd. (2016), çalışmalarında problem tiplerini, sunum, içerik ve çözüm şeklinde üç kategori altında sınıflandırmışlardır. Li vd. (2009), problem analizinde hesap içeren problem, sayısal ilişkilerin bilinmesini gerektiren problem ve sözel problem olmak üzere üç kategori kullanmışlardır. Yang vd. (2010), Singapur, Tayvan ve Amerika'da kullanılan matematik kitaplarında kesirler konusunda sorulmuş olan problemleri iki kategori (gerçek hayat problemi olup olmama, kavramsal/işlemsel anlamayı ölçme) altında sınıflandırmışlardır. Yang vd. (2017), geometri problemlerinin analizinde problemleri; sözel, sembolik, görsel ve karma formda sunulmuş problemler, gerçek hayatla ilgili, gerçek hayatla ilgili olmayan problemler, açik uçlu ve kapalı uçlu problemler şeklinde sınıflandırmışlardır. Bu çalışmada problemler Tablo 2'de verilen dört özellik açısından kategorilere yerleştirilmiştir. Adım sayısı özelliği, tek adımlı (T) ve çok adımlı (Ç) hesaplama gerektiren problemler olarak iki kategoride ele alınmıştır. Cevap tipi özelliği "sadece sayısal cevap gerektiren problemler (SC)", "çözümünde sadece sayılar ve bir veya daha fazla işlemsel semboller (+, -, x gibi) içeren problemler (Sİ)" ve "açıklama veya çözüm gerektiren problemler (AÇ)" olarak üç kategoriye ayrılmıştır. Problemler bağlam (context) açısından "yeterli, fazla ve eksik veri içeren problemler", "gerçek hayatla ilgili ve gerçek hayatla ilgisiz problemler", "sembolik, sözel, görsel ve birleştirilmiş formda sunulan problemler", "çözümü adım adım açıklanarak yapılmış olan paylaştırma ve ölçüm-tekrarlı çıarma problemleri”" şeklinde dört kategoride değerlendirilmiştir (Son ve Senk 2010; Son, 2012; Kar vd, 2018).

Kilpatrick vd. (2001), Li (2002); Son ve Senk (2010), Son (2012), Kar vd. (2018) çalışmalarında, bu üç özelliğe (problemin çözümündeki adım sayısı, cevap tipi ve içerik) ek olarak bilişsel beklenti özelliğini çalışmalarına dahil etmişlerdir. Bilişsel beklenti özelliği; kavramsal bilgi, işlemsel bilgi, matematiksel muhakeme, temsil, problem çözme kategorilerinden oluşmaktadır (Son ve Senk 2010; Son, 2012; Kar vd, 2018). Öğrenci, matematiksel bir problemi çözmek için, kullanacağı kuralın anlamını bilmek zorundaysa bu problem kavramsal bilgi kategorisine girmektedir. Örneğin, öğrencilerin kesirlerle bölme işlemi konusunu kavramsal olarak öğrenip öğrenmediklerini tespit etmenin yolu, öğrencilere bölme işleminde neden ters çevir çarp algoritmasına başvurduklarını sormak (Lin vd, 2013) ve ters çevir çarp algoritmasının neyi ifade ettiğini modeller kullanarak açıklamalarını istemektir (Chinnappan ve Forrester, 2014). Problem, öğrenciyi sadece prosedür ve algoritmaların kullanımı ile çözüm yapmayı gerektiriyorsa, problem işlemsel bilgi kategorisinde değerlendirilir. Prosedür bilgisi, prosedürlerin uygun bir şekilde ne zaman ve nasıl kullanılacağını bilmeyi gerektirir (Kilpatrick vd, 2001). Problemde öğrenciden çözüm stratejisini değerlendirmesi, çözümünü açılaması ve gerekçelendirmesi bekleniyorsa problem, 
matematik muhakeme kategorisine girmektedir. Öğrencinin problemi çözmesi için şekil, grafik ve tablo gibi görsel temsillerden yararlanması veya görsel temsilleri yorumlaması gerekiyorsa problem temsil kategorisinde yer almaktadır. Problem çözme kategorisi içine ise, çözmeleri için öğrencilere sunulan sözel-gerçek hayat problemleri girmektedir (Son ve Senk, 2010; Son, 2012). Matematiksel muhakeme kategorisine, ilerleyen yıllarda yapılmış çalışmalarda öğrencilerin cevapları tahmin etmelerini gerektiren problemlerde dahil edilmiştir (Son ve Hu, 2016; Kar vd, 2018). Kar vd. (2018), problem analizinde bilişsel beklenti özelliğine, problem ortaya atma kategorisini eklemişlerdir. Bu çalışmada bilişsel beklenti özelliği, "kavramsal bilgi", "işlemsel bilgi", "matematiksel muhakeme", "temsil", "problem çözme", "problem kurma" kategorilerinden oluşmaktadır. Problemlerin analizinde kullanılan teorik çerçeve Tablo 3'de verilmiştir.

Tablo 3. Problem Analizinin Teorik Çerçevesi

\begin{tabular}{|c|c|}
\hline Özellikler & Kategoriler (Kodlar) \\
\hline Adım Sayıs1 & Çok Adımlı Hesap (Ç) \\
\hline \multirow[t]{2}{*}{ Cevap Tipi } & Sadece sayısal cevap (SC) Sayısal ifade gerektiren (Sİ) \\
\hline & Açıklama veya çözüm gerektiren (AÇ) \\
\hline \multirow[t]{8}{*}{ Bağlam } & Yeterli Veri (YV)-İlgisiz Veri (IV)-Eksik Veri (EV) \\
\hline & Gerçek Hayat (GH)-Gerçek Hayatla İlgisiz (GHI) \\
\hline & Sembolik formda (SEF) \\
\hline & Sözel formda (SÖF) \\
\hline & Görsel formda (GÖF) \\
\hline & Çoklu Formda (Örneğin; Görsel+Sözel) (ÇOF) \\
\hline & Çözümlü Bölmenin Eşit Paylaşım Anlamına İlişkin Problem (ÇAP) \\
\hline & Çözümlü Bölmenin Ölçme Anlamına İlişkin Problem (ÇÖ) \\
\hline \multirow[t]{3}{*}{ Bilişsel Beklenti } & Kavramsal Bilgi (KB) \\
\hline & Matematiksel Muhakeme (MM) \\
\hline & Problem Çözme (PÇ) \\
\hline
\end{tabular}

Yukarıda verilen her bir kategoriye giren problem örnekleri Tablo 4'de verilmiştir. Tablo 4'ün altında problemlerin hangi kategoriye girdikleri nedenleriyle birlikte açıklanmıştır. Problemler ve girdikleri kategoriler oluşturulurken yapılmış çalışmalardan (Son ve Senk, 2010; Yang vd, 2010; Kar vd, 2018) yararlanılmıştır.

Tablo 4'te verilen birinci problem, iki alt problemden oluşmuştur. Dolayısıyla her bir problem ayrı bir problem olarak değerlendirmeye alınmıştır. Birinci ve altıncı problemlerin çözümleri tek adımda $(\mathrm{T})$ yapılabilecek ve cevabı sayısal ifade gerektirmektedir. Bir ve altı dışındaki problemler çok adımda yapılabilecek (Ç) türden olup açıklama ve çözüm gerektirmektedir. Örneğin, ikinci problemde öncelikle $\frac{2}{5} \div \frac{1}{10}$ işlemine ilişkin modelin oluşturulması ardından modelden yararlanılarak sonuca ulaşılması beklenmektedir. Tüm problemler yeterli veri içermektedir (YV). Üç numaralı problem dışındaki problemler gerçek hayatla ilgili (GHI) değildir. Bir ve iki numaralı problemler sembolik formda (SEF), üç ve yedi numaralı problemler sözel formda (SÖF), beş numaralı problem sözel ve görsel formda (ÇOF), altı numaralı problem ise görsel formdadır (GÖF). Kesirlerle bölme işleminin iki anlamı vardır. $\mathrm{Bu}$ anlamlardan ilki eşit paylaştırma diğeri ise ölçme (tekrarlı çıkarma) anlamıdır. Birinci soru işlemsel bilgi kategorisindedir. Çünkü bu soruyu çözerken öğrencilerin bölme algoritmasını kullanmaları yeterlidir. Yedinci soru kavramsal bilgi, temsil ve matematiksel muhakeme kategorilerinde yer almaktadır. Çünkü bu soruda öğrencilerden bölme işlemi ile çarpma işlemi arasındaki ilişkiyi görsel temsiller kullanarak ilişkilendirmeleri ve yaptıkları çözümü açıklamaları istenmektedir. 
Tablo 4. Problem Örnekleri ve Kodları (Son ve Senk, 2010, s.125; Kar vd, 2018, s.208). Örnekler

\begin{tabular}{cccc}
\multicolumn{4}{c}{ Kodlama } \\
\hline $\begin{array}{c}\text { Adım } \\
\text { Sayıs1 }\end{array}$ & Cevap & Bağlam & $\begin{array}{l}\text { Bilişsel } \\
\text { Bipi }\end{array}$ \\
T & Sİ* & YV, & İB \\
& & GHİ, &
\end{tabular}

2) (a) $\frac{2}{5} \div \frac{1}{10}=$ ? Kesir disklerini kullanarak sonuca ulaşınız.

3) $\frac{11}{4} l t$ süt $\frac{1}{4} l t^{\prime}$ lik şişelere doldurulmak isteniyor. Kaç şişeye ihtiyaç vardır. Bu işlemi şekil çizerek yaparak çözümünüzü açıklayınız.

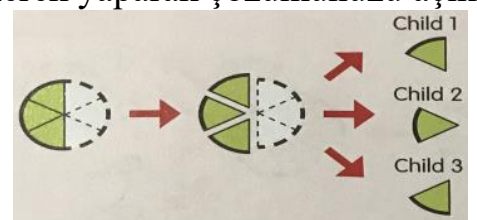

4)Yukarıdaki görsel her bir çocuğun aldığı pasta miktarını göstermektedir. $\mathrm{Bu}$ görsele uygun bir problem cümlesi yazınız.

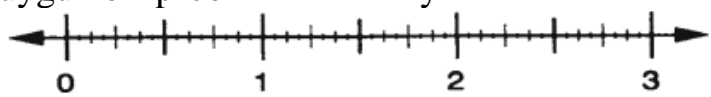

$\frac{3}{4} \div \frac{1}{2}$ işlemini yapınız. Çözüme nasıl ulaştığınızı açıklayınız.

6) Aşağıda verilen modellerde ifade edilen bölme işlemlerini örnekteki gibi noktalı yerlere yazınız (MB2 s.104).

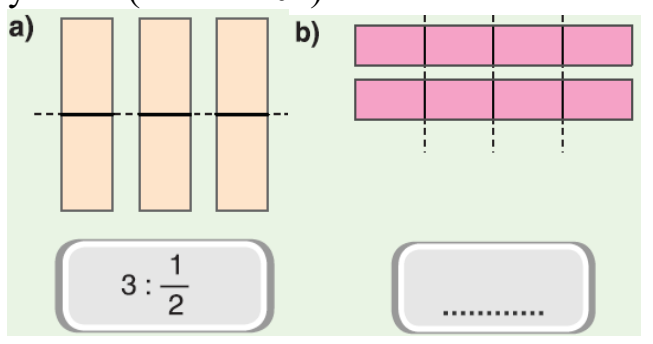

7) $\frac{4}{5} \div 2=\frac{4}{5} x \frac{1}{2}$ eşit olduğunu model üzerinde gösteriniz ve açıklayınız.
Ç

Ç

AÇ

YV,

ÇOF

SEF

YV,

GHİ,

SEF

$\mathrm{AÇ}$

YV, GH
SÖF

PÇ, MM,

$\mathrm{T}$

$\mathrm{PO}, \mathrm{T}$

$\mathrm{T}$

Sİ

$\mathrm{YV}$,

GHİ,

GÖF
MM, T

T
$\mathrm{T}$ 
temsil kategorisine, yaptıkları çözümleri açıklamaları istendiğinden matematiksel muhakeme kategorisine girmektedir. Bölme işleminin iki farklı anlamına ilişkin örnekler Tablo 5'te verilmiştir.

Tablo 5. Kesirlerle Bölme İşleminin İki Farklı Anlamına İlişkin Örnekler

\begin{tabular}{|c|c|c|}
\hline Anlamı & Eşit Paylaşım & Ölçme (Tekrarlı Çıkarma) \\
\hline Örnek Problem & $\begin{array}{l}\text { Bir pizzanın } \frac{2}{3} \text { 'si } 4 \text { çocuk } \\
\text { arasında eşit olarak } \\
\text { paylaştırılacaktır. Her bir } \\
\text { çocuk pizza'nın kaçta kaçını } \\
\text { alır? }\end{array}$ & $\begin{array}{l}\text { Ahmet bir ekmeğin } \frac{3}{4} \text { 'ünü eşit } \\
\text { parçalara bölüyor. Her bir parça } \\
\text { ekmeğin } \frac{1}{8} \text {; olduğuna göre, Ahmet } \\
\text { elindeki ekmeği kaç parçaya } \\
\text { bölmüştür? }\end{array}$ \\
\hline Eylem & $\begin{array}{l}\text { Verilen belli sayıdaki nesnenin } \\
\text { (Bir pizzanın } \frac{2}{3} \text { '̈ü), belli bir } \\
\text { gruba (4 çocuk) eşit olarak } \\
\text { paylaştırılması. Dikkat edilirse } \\
\text { bölmenin eşit paylaşım } \\
\text { anlamında grup sayısı bellidir. }\end{array}$ & $\begin{array}{l}\text { Dikkat edilirse bölmenin ölçme } \\
\text { anlamında grup sayısı belli değildir. } \\
\text { Amaç grup sayısını (ekmek parça } \\
\text { sayısı) bulmaktır. }\end{array}$ \\
\hline Sembolik Form & $\frac{2}{3} \div 4=\Delta$ & $\frac{3}{4} \div \frac{1}{8}=\Delta$ \\
\hline
\end{tabular}

Problemler bilişsel beklenti özelliği açısından değerlendirildiğinde, birinci problemde öğrencilerden sadece sonucu bulmaları beklendiğinden işlemsel bilgi kategorisindedir (IBB). İkinci problemde öğrencilerin $\frac{2}{5} \div \frac{1}{10}$ işleminin sonucunu kesir disklerini kullanarak bulmaları beklenmektedir dolayısıyla bu problem temsil kategorisindedir (T). Üçüncü problem bir sözel gerçek hayat problemidir ve çözümünün model kullanılarak yapılması ve çözümün açıklanması istenmektedir dolayısıyla bu problem, problem çözme (PÇ), temsil (T) ve matematiksel muhakeme (MM) kategorisindedir. Dördüncü soruda öğrencilerden verilen görseli yorumlayarak ve kesirlerle bölme işlemi ile ilişkilendirerek bir problem cümlesi yazmaları beklenmektedir. Dolayısiyla bu soru temsil (T) ve problem ortaya atma (PO) kategorilerine alınmıştır. Beşinci soru, öğrencilerin sayı doğrusunu kullanarak $\frac{3}{4} \div \frac{1}{2}$ işlemini yapmaları bakımından temsil (T) kategorisine, yaptıkları çözümü açıklamaları açısından, matematiksel muhakeme (MM) kategorisine uygundur. Altıncı soruda öğrencilerin görsellere uygun sembolik ifadeyi yazmaları beklendiğinden bu soru temsil (T) kategorisinde bulunmaktadır. Son soruda, öğrencilerden kesir bölmesinde, ters çevir çarp algoritmasını neden kullanıldığını model kullanarak göstermeleri ve açıklamaları istendiğinden bu problem kavramsal bilgi (KB), matematiksel muhakeme (MM) ve temsil (T) kategorisine girmektedir.

Ders kitaplarında yer alan problemlerin analizi matematik eğitimcisi olan ve ölçmedeğerlendirme üzerine akademik çalışmaları olan iki akademisyen tarafindan yapılmıştır. Her bir kategori için yapılan analizlerin Cohen Kappa uyum indeksi hesaplanmıştır. Örneğin iki araştırmacı, problemleri, adım sayısı özelliği bakımından tek adımlı (1), çok adımlı (2) şeklinde kodlamışlardır. Benzer şekilde, araştırmacılar bağlam açısından problemleri sembolik form (1), sözel form (2), görsel form (3), çoklu form (4) şeklinde kodlamışlardır. Diğer özellikler açısından da benzer kodlamalar yapılmıştır. Ardından yapılan kodlamalar SPSS programına girilerek adım sayısı özelliği açısından araştırmacılar arasındaki uyum değeri bulunmuştur. 
Yapılan kodlamalar arasındaki uyum indeksi, her bir kategori için 0.98-1.00 arasında bulunmuştur. Bu sonuç kodlayıcılar arasında neredeyse mükemmel bir uyumu göstermektedir (Cohen, 1960; Viera ve Garrett, 2005). İki araştırmacının kodlama noktasında uzlaşamadığı problemler bir kağıda not alınmış, bu problemlerin kodlanmasında matematik eğitimi alanında uzman, ölçme ve değerlendirme üzerine çalışmaları olan farklı bir araştırmacıdan görüş alınmıştır. Üç uzman arasında yapılan tartışmalar neticesinde, çoğunluğun görüşüne bağlı olarak problemlerle ilgili nihai karar verilmiştir. Bir sonraki kısımda çalışmanın bulguları sunulmuştur.

\section{Bulgular}

Bulgular, öncelikle adım sayısı, cevap tipi ve bağlam açısından problemlerin analizinden elde edilen bulgular, ardından bilişsel beklenti özelliği açısından problemlerin analizinden elde edilen bulgular şeklinde sunulmuştur.

\section{Adım Sayısı, Cevap Tipi ve Bağlam Açısından Problemlerin Karşılaştırılması}

Ders kitaplarında yer alan problemler öncelikle adım sayısı, cevap tipi ve bağlam özellikleri açısından analiz edilmiş, elde edilen bulgular Tablo 6'da sunulmuştur.

Tablo 6. Ders Kitaplarında Problemlerin Dağılımı

\begin{tabular}{lccc}
\hline \multicolumn{1}{c}{ Kategoriler } & $\begin{array}{c}\text { TB1 f(\%) } \\
{[N=67]}\end{array}$ & $\begin{array}{c}\text { TB2 f(\%) } \\
{[N=37]}\end{array}$ & $\begin{array}{c}\text { MP f(\%) } \\
{[N=80]}\end{array}$ \\
\hline Adım Sayısı & & & \\
Tek Adımlı Hesap (T) & 64 & 37 & 56 \\
Çok Adımlı Hesap (Ç) & 3 & 0 & 24 \\
Cevap Tipi & & & \\
Sadece Sayısal Cevap (SC) & 8 & 6 & 17 \\
Sayısal İfade Gerektiren (Sİ) & 57 & 31 & 42 \\
Açıklama veya Çözüm Gerektiren (AÇ) & 2 & 0 & 21 \\
Bağlam & & & \\
Yeterli Veri (YV) & 67 & 37 & 80 \\
İlgisiz Veri (İV) & 0 & 0 & 0 \\
Eksik Veri (EV) & 0 & 0 & 0 \\
Gerçek Hayat (GH) & 17 & 3 & 11 \\
Gerçek Hayatla İlgisiz (GHI) & 50 & 34 & 69 \\
Sembolik Formda (SEF) & 48 & 26 & 50 \\
Sözel Formda (SÖF) & 19 & 7 & 3 \\
Görsel Form (GÖF) & 0 & 4 & 0 \\
Çoklu Formda (Örneğin; Görsel+Sözel) (ÇOF) & 0 & 0 & $\mathbf{2 7}$ \\
Eşit Paylaşım Anlamına İlişkin Problem (ÇAP) & 5 & 2 & 7 \\
Bölmenin Ölçme Anlamına İlişkin Problem & 12 & 10 & 9 \\
(ÇÖ) & & & \\
\hline
\end{tabular}

Kitaplardaki problemlerin çoğu tek adımda çözülebilen tiptedir. Ancak Singapur ders kitabında çok adımda çözülebilecek problem sayısı, Türk ders kitaplarına kıyasla daha fazladır. MP kodlu kitapta 24 adet çok adımda çözülebilecek problem vardır. TB1 kodlu kitapta sadece 3 tane çok adımda çözülebilecek problem yer almaktadır. TB2 kodlu kitapta ise çok adımda çözülebilecek problem bulunmamaktadır. Kitaplardaki problemlerin çoğunluğu sadece sayısal ifade gerektiren tiptedir. Türk kitaplardaki problemlerin neredeyse tamamında, öğrencilerden çözümlerini açıklamaları ve problem çözümünde model kullanmaları beklenmemektedir. Aksine Singapur ders kitabında yer alan 21 problemde öğrencilerden açıklama veya çözüm 
yapmaları istenmiştir. İki ülke kitaplarındaki kesirde bölme problemlerinin tamamı, yeterli veri içermektedir. Genel olarak bakıldığında tüm kitaplardaki gerçek hayatla ilgili problem sayısı az olmakla birlikte, en az gerçek hayata dair problemin bulunduğu kitap, TB2 kodlu Türk kitabıdır. Kitaplardaki problemlerin çoğunluğu sembolik formda olmasına karşın, görsel ve sembolik formun (ÇOF) her ikisinin de kullanıldığı problemler sadece Singapur kitabında yer almaktadır. Bunun yanında, Türk kitaplarından farklı olarak Singapur kitabında 9 adet çözümü belli bir noktaya kadar yapılmış, devamı öğrencilere bırakılmış (half worked-out examples) problem bulunmaktadır. Şekil 1 ve Şekil 2'de Singapur kitabında yer alan çoklu formda çok adımlı, açıklama ve çözüm istenen problem örneği verilmiştir.

Alice had $\frac{1}{4}$ of a pizza. She shared the pizza equally with her brother. Use $\frac{1}{2}$ to show how much pizza each of them received. Explain.

Şekil 1. Sözel-gerçek hayat problem örneği [Alice bir pizzanın $\frac{1}{4}$ 'ine sahiptir. Alice, pizzasını erkek kardeşi ile eşit olarak paylaşacaktır. Her birinin ne kadar pizza aldığını göstermek için kesir diskini kullan ve çözümünü açıkla] (MP6A, s.34).

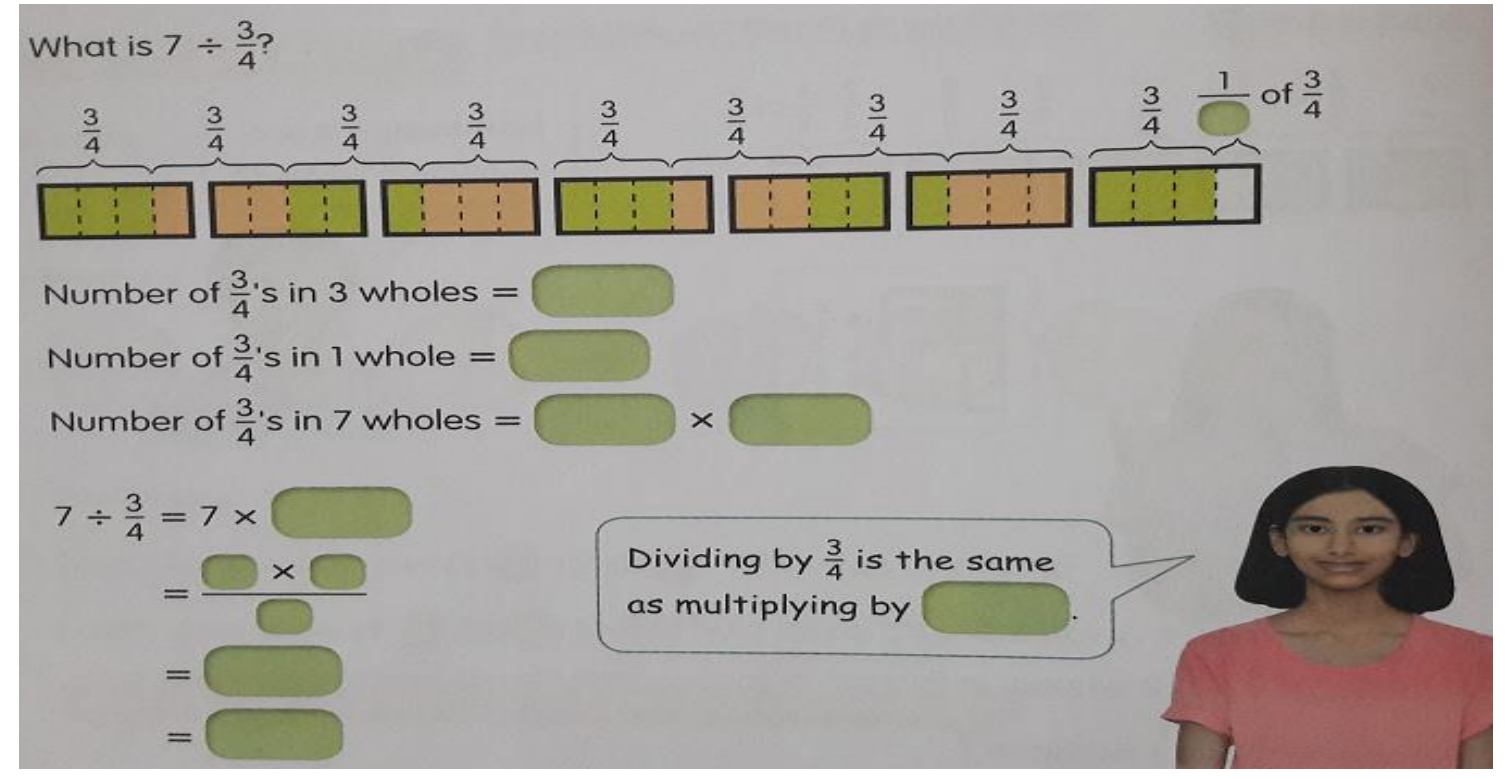

Şekil 2. Çoklu form'da çok adımlı, kısmi çözümlü bir problem $\left[7 \div \frac{3}{4}\right.$ işleminin sonucunu bulunuz? 3 tam içindeki $\frac{3}{4}$ 'lerin sayısı nedir?, 1 tam içindeki $\frac{3}{4}$ 'lerin sayısı nedir?, 7 tam

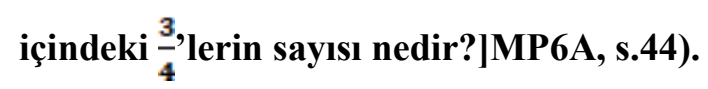


Her iki ülkenin matematik ders kitaplarında çözümü adım adım açıklanarak yapılmış olan paylaştırma ve ölçüm problemine yer verilmiştir. TB1'de 5 adet eşit paylaşım, 12 adet ölçme-tekrarlı çıkarma anlamlarına odaklanan problemlerin, TB2'de 2 adet eşit paylaşım, 10 adet ölçme -tekrarlı çıkarma anlamlarına odaklanan problemlerin çözümü adım adım açıklanmıştır. MP kodlu kitapta çözümü adım adım açıklanan 7 tane eşit paylaşım problemi, 9 tane ölçme (tekrarlı çıkarma) problemi bulunmaktadır.

“Ali bir pizzanın $\frac{2}{3}$ 'ünü eşit parçalara bölüyor. Her bir parça pizzanın $\frac{\mathbf{1}}{6}{ }^{\prime}$ i olduğuna göre, Ali elindeki pizzayı kaç parçaya bölmüştür” (MP 6A, s.45; Ölçme-Tekrarlı Çıkarma Problemi)

"Bir pizzanın $\frac{4}{5}, \ddot{\text { ü }} 4$ çocuk arasında eşit olarak paylaştırılacaktır. Her bir çocuk pizzanın kaçta kaçını alır" (TM 6A, s.30; Eşit Paylaşım Problemi)

Bir sonraki kısımda, bilişsel beklenti özelliği açısından problemlerin analizinden elde edilen bulgulara yer verilmiştir.

\section{Bilişsel Beklenti Özelliği Açısından Problemlerin Karşılaştırılması}

Problemler bilişsel beklenti özelliği açısından analiz edildiğinde Tablo 7'deki bulgulara ulaşılmıştır.

Tablo 7. Ders Kitaplarında Yer Alan Problemlerin Bilişsel Beklenti Özelliğine Göre Dağılımı

\begin{tabular}{lccc}
\hline Bilişsel Beklenti & TB1 f(\%) & TB2 $\mathrm{f}(\%)$ & MP f(\%) \\
\hline İşlemsel Bilgi (İB) & 55 & 29 & 45 \\
Kavramsal Bilgi (KB) & 0 & 0 & 12 \\
Temsil (T) & 2 & 4 & 34 \\
Problem Çözme (PÇ) & 19 & 3 & 10 \\
Matematiksel Muhakeme (MM) & 0 & 2 & 23 \\
Problem Kurma (PO) & 0 & 0 & 0 \\
\hline
\end{tabular}

Türk ve Singapur kitaplarındaki problemlerin çoğunluğu işlemsel anlamayı ölçmeyi hedeflemektedir. Türk kitaplarında kavramsal anlamayı ölçmeye dönük problem bulunmamaktadır. Sadece MP kodlu Singapur kitabında 12 adet kavramsal bilgi kategorisinde olan problem yer almaktadır. Bu problemlerde öğrencilerden kesirlerle bölme işleminde neden ters çevir çarp algoritmasının kullanıldığını düşünmeleri ve yorumlamaları beklenmektedir. Öğrencilerin problemi çözmesi için şekil, grafik ve tablo gibi görsel temsillerden yararlanmasını veya görsel temsilleri yorumlamasını gerektiren problem sayısı Singapur kitabında, Türk kitaplarına kıyasla fazladır. Singapur kitabında 34 problem temsil kategorisindedir. TB1 ve TB2 kodlu kitaplarda temsil kategorisinde yer alan soru sayısı sırasıyla 2 ve 4 'tür. Singapur kitabında kavramsal bilgi ve temsil kategorilerinde yer verilen problem örneği aşağıda verilmiştir. Problem çözme kategorisine giren problem sayısının en az olduğu kitap TB2'dir. Matematiksel muhakeme kategorisi açısından en fazla soru MP kodlu Singapur kitabında bulunmaktadır. TB1 kodlu kitapta matematiksel muhakeme kategorisine giren hiçbir soru yoktur. Ayrıca kitapların 
hiçbirinde öğrencilerin kesirlerle bölme işlemi ile ilgili sembolik veya görsel formda verilmiş bir temsile ilişkin, problem kurmalarını gerektiren bir soru bulunmamaktadır. Singapur kitabında matematiksel muhakeme, temsil ve kavramsal bilgi kategorisine giren problem örneği Şekil 3’te verilmiştir.

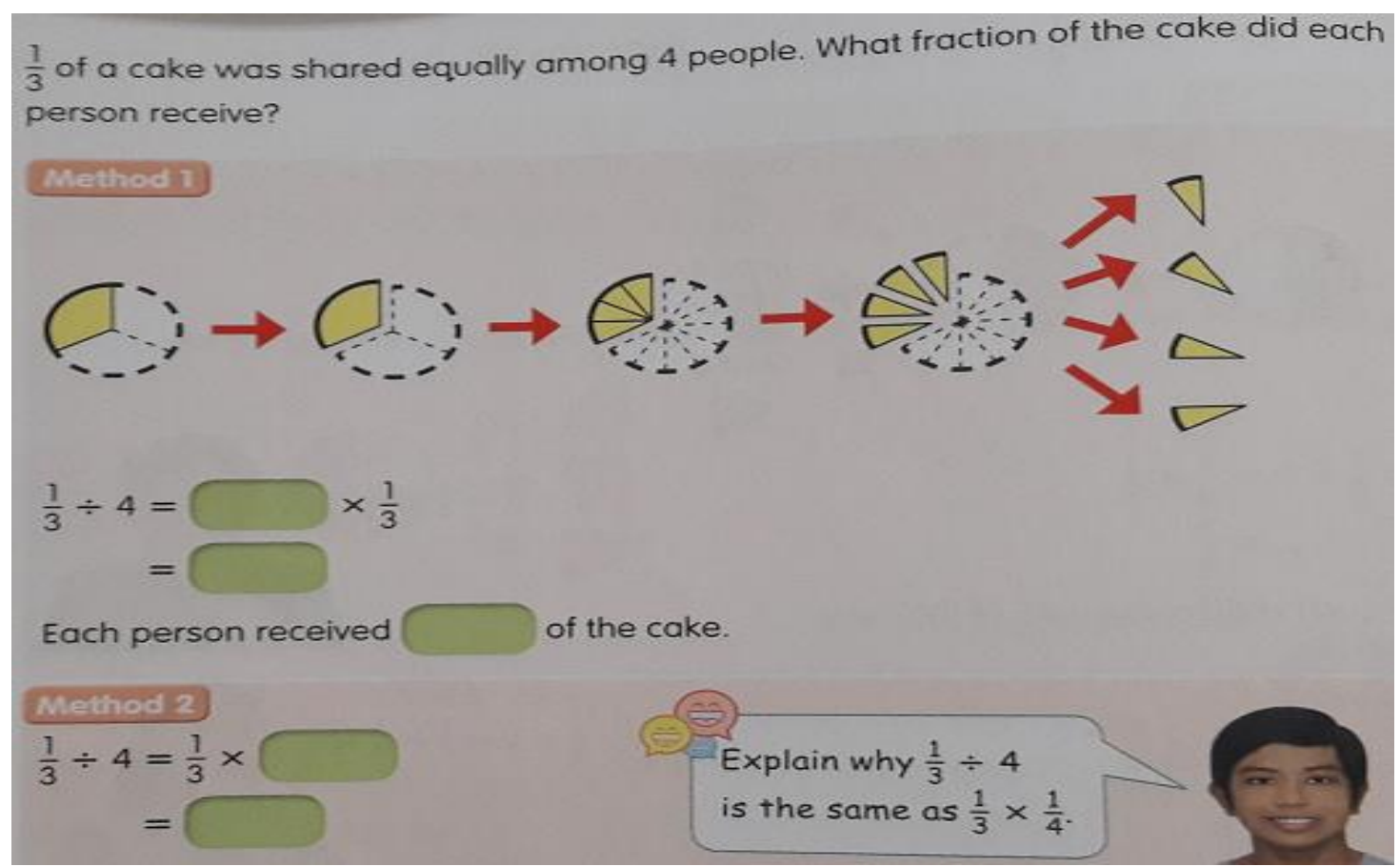

Şekil 3. Muhakeme, temsil ve kavramsal bilgi kategorisinde yer alan problem [Bir kekin $\frac{1}{3}^{t} i 4$ kişi arasında eşit olarak paylaştırılıyor. Her bir kişi kekin ne kadarını alır?] (MP6A, s.36)

Şekil 3'de sözel ve görsel formda (ÇOF) verilen sözel-gerçek hayat probleminde, öğrencilerden görsel temsili kullanarak problemi çözmesi beklenmektedir. Bu açıdan problem temsil kategorisindedir. Ayrıca öğrencilerden kesirlerle bölme işleminde neden "ters çevir çarp" algoritmasının kullanıldığını açıklamaları istenmektedir. Bu açıdan problem kavramsal bilgi ve matematiksel muhakeme kategorisinde yer almaktadır.

\section{Tartışma ve Sonuç}

Bu çalışmada, Türk ve Singapur ders kitapları, çoğu öğrencinin anlamakta zorlandığı kesirlerle bölme işlemi konusunda yer alan problem tipleri açısından karşılaştırılmıştır. Her iki ülkede kullanılan ders kitaplarındaki çoğu problem, tek adımda çözülecek sayısal ifade gerektiren problemlerdir. Benzer şekilde, Son ve Senk (2010), Kore ve Amerika ders kitaplardaki problemlerin çoğunun tek adımlı olduğu ve sadece sayısal cevap gerektirdiği sonucuna ulaşmışlardır. Her iki ülkede kullanılan ders kitaplarındaki çoğu problem, tek adımda çözülecek sayısal ifade gerektiren problemler bulunsa da, Türk kitaplarına kıyasla, Singapur kitabında çok adımlı hesap, açıklama-çözüm gerektiren ve kavramsal anlamayı ölçmeyi amaçlayan problem sayısı daha fazladır. Uluslararası sınavlarda ilk sıralarda yer alan diğer ülkelerin (Çin, Kore) kitaplarının kullanıldığı karşılaştırma çalışmalarında da benzer sonuçlara ulaşılmıştır. Örneğin, Zhu ve Fan (2006), Çin kitaplarının, Amerika kitaplarına kıyasla çok adımlı çözüm gerektiren 
sorular açısından daha zengin olduğu sonucuna, Li vd. (2009) Kore kitaplarının, Amerika ders kitaplarına kıyasla, daha karmaşı yapıda hesap içeren problemler içerdiği sonucuna ulaşmışlardır. Stein vd'e (2007) göre, ders kitaplarında ne tip problemlerin kullanıldığı, öğrencilerin uluslararası sınavlardaki (TIMSS, PISA) performanslarını etkilemektedir. Nitekim, Ulusal Eğitim Sürecini Değerlendirme Kurumu (NAEP- National Assessment of Educational Progress) raporu, çoğu Amerikalı ilkokul öğrencilerinin çok adımlı işlem gerektiren problemlerde zorlandıklarını ortaya koymaktadır (Carpenter vd, 1980). Bu açıdan iki ülkede kullanılan matematik ders kitapları; çok adımda çözülebilen, açıklama ve çözüm gerektiren problemler açısından zenginleştirilmelidir.

Eksik veya fazla veri içeren problemler, incelenen ders kitaplarında yer almamaktadır. Fan ve Zhu (2000) çalışmalarında basım yılı 1997 olan iki adet Singapur kitabı (New Syllabus D Mathematics 1-2) üzerinde problem analizi gerçekleştirmişlerdir. Çalışmalarının sonucunda Singapur kitabındaki problemlerin tamamına yakınının yeterli veri içerdiğini tespit etmişlerdir. Ders kitaplarındaki problemlerin neredeyse tamamının yeterli veri içeriyor olması, öğrencileri karşılarına çıkan her problemin yeterli veri içerdiğini ve problemleri çözmek için problemde verilen tüm bilgilerin kullanılması gerektiğini düşünmeye iter. Ancak bu düşünce, öğrencilerin ihtiyaç duydukları bilgileri aktif olarak toplaması, seçmesi ve değerlendirmesi gereken, gerçek hayat problemlerini çözmede gerçekçi olmayabilir (Fan ve Zhu, 2000). Bu yüzden öğrencilerin gerçek hayat problemlerinin çözümünde başarılı olabilmeleri için, Türk ve Singapur matematik ders kitaplarının eksik ve fazla veri içeren problemler açısından zenginleştirilmesinin gerekli olduğu söylenebilir.

Ders kitaplarında gerçek hayat problem sayısı azdır. TB1 kodlu kitaptaki problemlerin $\% 25$ 'i, TB2 kodlu kitaptaki problemlerin \%8'i, Singapur kitabındaki problemlerin ise \%14'ü gerçek hayat problemidir. Bunun yanında ders kitaplarındaki kesirlerle bölme işlemi ile ilgili tüm problemler kapalı uçludur. Elde edilen sonuçlar, Singapur müfredat çerçevesinde, öğrencilerde muhakeme, iletişim, ilişkilendirme ve modelleme gibi matematiksel süreç becerilerinin harekete geçirilebilmesi için öğrencilerin gerçek hayat problemleriyle ve açık uçlu problemlerle karşı karşıya gelmeleri gerektiği (Foong, 2009; Ibrahim ve Othman, 2010; MOES, 2012) görüşüyle zıtlık göstermektedir. Bunun yanında TB1 kodlu kitaptaki problemlerin dörtte birinin gerçek hayat problemi olmasına karşın, TB2 kodlu kitapta sadece üç adet gerçek hayat probleminin yer alması ders kitaplarının hazırlanma aşamasında ortak bir görüşün benimsenmesi gereğini ortaya koymaktadır. Fan ve Zhu (2000), inceledikleri Singapur kitaplarındaki problemlerin \%2'ye yakınının gerçekçi günlük hayat durumlarını yansıttığını tespit etmişlerdir. Literatürde gerçek hayat problemlerinin yararlarından bahsedilmektedir. Gerçek hayat problemleri öğrencilerin dikkatini çekmekte ve problemi çözmek için motivasyonlarını arttırmaktadır (Yang ve Wu, 2010; Van de Walle vd, 2010). Gerçek hayat problemleri öğrencilere var olan bilgi şemaları ile yeni bilgiyi ilişkilendirebilme fırsatı sağladığından, öğrencilerin matematiği öğrenmelerine yardımcı olmaktadır (Gravemeijer vd, 2000). Bu bakımdan iki ülke ders kitapları, gerçek hayat problemleri ile zenginleştirilmelidir.

Ders kitaplarındaki problem yapıları analiz edildiğinde, tüm kitaplarda adım adım çözümü açıklanarak yapılan (worked-out example), eşit paylaşım ve ölçme-tekrarlı çıkarma (grup sayısını bulma) problemlerinin bulunduğu tespit edilmiştir. Singapur kitabında, bölme işleminin eşit paylaşım ve ölçme anlamlarına uygun problemler sayıca birbirine yakın iken, 
Türk kitaplarında ağırlıklı olarak bölmenin ölçme anlamına uygun problemler yer almaktadır. Öğrencilerin kesirlerle bölme işleminin tüm anlamları üzerine düşünebilmeleri için bölme işleminin eşit paylaşım ve ölçme (tekrarlı çıkarma) anlamlarına uygun problemlerin ders kitaplarına dengeli bir şekilde dağıtılması gerekmektedir (Van de Walle vd, 2010).

Türk kitaplarında, Singapur kitabına kıyasla kavramsal bilgi ve matematiksel muhakeme kategorisine giren problemlere yeterli düzeyde yer verilmediği tespit edilmiştir. Her iki ülkenin matematik müfredatının çerçevesi incelendiğinde, kavramsal bilgi ve muhakeme kategorisine giren problemlerin yer alması gerektiğine işaret edilmektedir. Örneğin, Singapur matematik müfredatında, öğrencilerin bilişüstü farkındalık düzeyinin gelişimi için, öğrencilerin açık uçlu problemler üzerinden yaptıkları çözümleri tartışmalarına firsatlar sunmanın önemine temas edilmiştir (MOES, 2012). Uluslararası sınavlarda ilk sıralarda yer alan diğer ülkelerin (Kore) kitaplarının kullanıldığı karşılaştırma çalışmalarında da benzer sonuçlara ulaşılmıştır. Örneğin, Son ve Senk (2010), sayısal ifade, çözüm ve açılama gerektiren, muhakeme becerisini yoklayan soru sayısının, Amerika kitaplarına kıyasla Kore kitaplarında daha fazla olduğunu tespit etmişlerdir. Kar vd, (2018) çalışmalarında, Amerika ders kitaplarında öğrencilerin kavramsal anlamalarını ve muhakeme becerilerini yoklayan problem sayısının, Türk kitaplarına kıyasla fazla olduğunu tespit etmişlerdir. Elde edilen sonuçlar Türk ders kitaplarının kavramsal bilgi ve muhakeme kategorilerine giren problemler açısından zenginleştirilmesi gerektiğini göstermektedir.

Her iki ülkenin kitabında da kesirlerle bölme işleminin zihinden nasıl yapılması gerektiğine ve bununla ilgili problem durumlarına ilişkin bir içerik yer almamaktadır. Kesirlerle bölme işleminin sonucunun tahmin edilmesine ilişkin problemler, Türk ders kitaplarında yer alırken, Singapur kitabında bu tip problemlere yer verilmemiştir. Ancak Türk kitaplarında öğrencilerden sadece kesirlerle bölme işlemini tahmin etmeleri beklenmiş, öğrencilerin tahmin sürecinde hangi stratejilere başvurdukları sorgulanmamış ve öğrenciler başvurdukları stratejiler hakkında akranlarıyla bir tartışma ortamına sokulmamışlardır. Yukarıdaki bulguya paralel olarak, çoğu Asyalı öğrencinin kuralların bir işe yaramadığı, hesaplamalı tahmin problemlerinin çözümünde başarısız olduklarını ifade edilmektedir (Verschaffel vd, 2007; Yang vd, 2009). Ancak şu da bir gerçektir ki, matematiksel muhakeme gerektiren tahmin ve zihinden hesap sorularının ders kitaplarında bulunması öğrencilerin bu tür problemlerde başarılı olması için gerekli ancak tek başına yeterli değildir. Nitekim Türk öğrencilerinin tahmin ve zihinden işlem performanslarının düşük olduğunu ortaya koyan birçok çalışma mevcuttur (Şengül ve Gülbağcı, 2012; İymen ve Duatepe-Paksu, 2015; Bütüner, 2018).

Türk ve Singapur kitaplarında yer alan problemlerin çoğu sembolik veya sözel formdadır. Benzer olarak Kar vd. (2018), Türk ve Amerikan kitaplarındaki problemlerin yarısından fazlasının sözel veya sembolik formda olduğunu tespit etmişlerdir. Türk kitaplarında çoklu formda sorulmuş hiçbir soru bulunmamaktadır. Aksine Singapur kitabında çoklu formda sorulmuş yirmi yedi adet soru bulunmaktadır. Türk kitaplarında Singapur kitabına kıyasla, öğrencinin problemi çözmesi için şekil, grafik ve tablo gibi görsel temsillerden yararlanmasını veya görsel temsilleri yorumlamasını gerektiren az sayıda problem bulunmaktadır. Bu sonucun ortaya çıkmasının olası sebeplerinden biri, Singapur matematik öğretim programında aritmetik ve cebir problemlerinin çözümünde "model yönteminin" benimsenmiş olmasıdır. Bu yaklaşımda sayılar ve bilinmeyenleri göstermek için görsel temsil olarak dikdörtgenler kullanılmaktadır. 
Singapur matematik öğretim programında, sözel formda verilmiş olan problemler görsel formda ifade edildikten sonra sembolik forma geçiş yapılmaktadır. Bu açıdan Singapur ders kitaplarında temsiller arası geçiş sıklıkla "sözel-görsel-sembolik" sırasını takip etmektedir (Fong ve Lee, 2009). Yapılmış çalışmalar, Amerika ders kitaplarında, Çin kitaplarına kıyasla görsel formda sunulmuş problemlerin fazla olduğunu bu yüzden Amerikalı öğrencilerin Çinli öğrencilere kıyasla problem çözümlerinde görsel temsili kullanmayı daha çok tercih ettiklerini ortaya koymaktadır (Cai, 1995; Brenner vd, 1999). Matematik derslerinde çoğu zaman öğrencilere sembolik formda veya sözel formda sunulmuş bir problem verilerek, öğrencilerden problemi sembolik formda çözmeleri beklenmektedir. Bu açıdan ders kitaplarının öğrencilerin temsiller arası geçiş yapmalarına olanak sağlayan problem yapılarıyla zenginleştirilmesi faydalı olacaktır. $\mathrm{Bu}$ tarz problemler öğrencileri, kavramsal öğrenme sürecine sokmakta (Duval, 2006), öğrencilerde zengin bir kavram imajının oluşmasına imkan tanımaktadır (Tall, 1988). Bu açıdan Türk ders kitaplarının temsil kategorisine giren problemlerle zenginleştirilmesi gerekmektedir.

İki ülkenin ders kitabında da problem kurma çalışmasına yer verilmemiştir. Matematikte problem çözme yeteneğini geliştirmenin temel hedefi iyi problem çözen öğrenciler yetiştirmek olup bunun yanında iyi problem kuran öğrenciler haline gelmelerini sağlamaktır. Bu yüzden, problem kurma etkileşimli öğrenme ve öğrencilerin üstbilişsel aktivitelerinin gelişimini içeren bir başka problem çözme deneyimidir (Foong, 2009). Problem kurma çalışmaları, öğrencilerin problem çözme yetenekleri, yaratıcılıkları ve kavramsal öğrenmeleri üzerinde olumlu etkiye sahiptir. Çünkü öğrenciler problem kurma çalışmalarında sembolik veya görsel formda verilmiş olan matematiksel bir ifadeyi, sözel formda ifade etmeye çalışırlar (Silver, 1994; Cai ve Hwang, 2002). Bu açıdan Türk ve Singapur ders kitaplarında kesirlerle bölme işlemi ile ilgili problem kurma çalışmalarına yer verilmesi gerekmektedir.

Stein vd. (2007), ders kitaplarında yer alan problem tiplerinin öğrencilerin uluslararası sınavlardaki performanslarına yansıyacağını vurgulamışlardır. Uluslararası matematik ve fen eğilimleri araştırmasında (TIMSS); bilme, uygulama ve muhakeme bilişsel alanlarından sorular sorulmaktadır. Soruların üçte ikisi uygulama ve muhakeme düzeyindedir. Öğrencilerin, kesirlerle bölme işlemi ile ilgili uygulama düzeyindeki soruları çözebilmeleri için, kesirlerle bölme işlemi içerisinde yer alan stratejilerin ve algoritmaların anlamlarını ve neden kullandıklarını bilmeleri gerekmektedir. Aynı araştırmada (TIMSS), öğrencilere muhakeme düzeyinde açık uçlu ve çok adımlı sorular sorulmaktadır. Muhakeme düzeyindeki sorularda, öğrencilerden yaptıkları çözümü açıklamaları ve farklı çözüm stratejileri kullanmaları beklenir ve yapılan doğru çözüm iki puan olarak değerlendirilir (Mullis vd, 2015). Singapur kitabının, Türk kitaplarına kıyasla kavramsal bilgi, temsil ve muhakeme kategorilerine giren problemler açısından zengin oluşu, Singapur'un uluslararası sınavlarda sayılar öğrenme alanı özelinde Türkiye'nin önünde yer alması ile uyumlu görünmektedir. Ancak bu çalışmadan elde edilen sonuçlara temkinli yaklaşılmalıdır. Çünkü öğrencilerin matematik başarılarını etkileyen birçok faktör (anne baba eğitim düzeyi, evdeki eğitsel kaynak sayısı, öğretmen rolü vb.) vardır. Çok iyi hazırlanmış veya hazırlanmamış bir ders kitabı, donanımlı bir öğretmenin elinde hayat bulacaktır. Çalışmadan elde edilen sonuçlara göre, her iki ülke ders kitaplarına farklı tipteki problemler dengeli şekilde dağıtılmalıdır. Özellikle Türk ders kitapları; kavramsal bilgi, matematiksel muhakeme ve temsil kategorilerinde yer alan problemler açısından zenginleştirilmelidir. Bu çalışmanın devamında, matematik öğretmenlerinin ders kitaplarındaki 
problemlerden ne ölçüde yararlandıkları ve derslerinde ne tip problemlere yer verdikleri araştırılarak ortaya çıkan bulgular, öğretim programının özel amaçları açısından irdelenebilir.

\section{Kaynakça}

Alajmi, A. M. (2012). How do elementary textbooks address fractions? A review of mathematics textbooks in the USA, Japan and Kuwait. Educational Studies in Mathematics, 79, 239-261.

Black, P., \& Wiliam, D. (1998). Inside the black box: raising standards through classroom assessment. Phi Delta Kappan, 80(2), 139-148.

Brenner, M.E., Herman, S., Ho, H. \& Zimmer, J.M. (1999). Cross-national comparison of representational competence. Journal for Research in Mathematics Education, 30(5), 541557.

Brown, G., \& Quinn R. J. (2007). Fraction proficiency and success in algebra: What does research say?. Australian Mathematics Teacher, 63(3): 23-30.

Bütüner, S. Ö. (2018). Comparing the use of number sense strategies based on student achievement levels. International Journal of Mathematical Education in Science and Technology, 49(6), 824-855.

Cai, J. (1995). A cognitive analysis of U.S. and Chinese students' mathematical performance on tasking involving computation, simple problem solving, and complex problem solving. Journal for Research in Mathematics Education (Monograph series 7). Reston, VA: National Council of Teachers of Mathematics.

Cai J., \& Hwang S. (2002). Generalized and generative thinking in US and Chinese students'mathematical problem solving and problem posing. The Journal of Mathematical Behavior, 21, 401-421.

Carpenter, T. P., Corbitt, M. K., Kepner, H. S., Lindquist, M. M., \& Reys, R. E. (1980). Solving verbal problems: Results and implications from national assessment. Arithmetic Teacher, 28(1), 812.

Carpenter, T. C., Lindquist M. M., Brown C. A., Kouba V. L., Silver E. A., \& Swafford J. O. (1988). Results of the fourth NAEP assessment of mathematics: Trends and conclusions. Arithmetic Teacher, 36(4), 38-41.

Charalambous, C. Y., Delaney S., Hsu. H. Y., \& Mesa V. (2010). A Comparative analysis of the addition and subtraction of fractions in textbooks from three countries. Mathematical Thinking and Learning, 12 (2), 117-151.

Chinnapan, M., \& Forrester, T. (2014). Generating procedural and conceptual knowledge of fractions by pre-service teachers. Mathematics Education Research Journal, 26(4), 871-896.

Cohen, J. (1960). A coefficient of agreement for nominal scales. Educational and Psychological Measurement, 20(1), 37-46.

Dindyal, J. (2006). The Singaporean Mathematics Curriculum: Connections to TIMSS. https://repository.nie.edu.sg/handle/10497/14374 adresinden 05.04.2019 tarihinde indirilmiştir.

Duval, R. (2006). A cognitive analysis of problems of comprehension in a learning of Mathematics. Educational Studies in Mathematics, 61, 103-131.

Erbaş A. K., Alacacı C., \& Bulut M. A. (2012). Comparison of mathematics textbooks from Turkey, Singapore and the United States of America. Educational Sciences: Theory and Practice, 12(3), $2311-2329$.

Fan, L., \& Zhu, Y. (2000). Problem solving in Singaporean secondary mathematics textbooks, The Mathematics Educator, 5(1), 117-141.

Foong, P. Y. (2009). Review of Research on Mathematical Problem Solving in Singapore. In W. K. Yoong, L. P. Yee, B. Kaur, F. P. Yee, \& N. S. Fong (Eds.), Mathematics education: the Singapore journey (pp.263-300). World Scientific Publishing: Singapore. 
Fong, N. S., \& Lee, K. (2009). Model Method: A Visual Tool to Support Algebra Word Problem Solving at the Primary Level. In W. K. Yoong, L. P. Yee, B. Kaur, F. P. Yee, \& N. S. Fong (Eds.), Mathematics education: the Singapore journey (pp.169-203). World Scientific Publishing: Singapore.

Gravemeijer, K., Cobb, P., Bowers, J., \& Whitenack, J. (2000). Symbolizing, modeling, and instructional design. In P. Cobb, E. Yackel, \& K. McClain (Eds.), Communicating and symbolizing in mathematics: Perspectives on discourse, tools, and instructional design (pp. 225-274). Mahwah, NJ: Lawrence Erlbaum Associates.

Güven, D. (2014). Ortaokul 6. sinıf matematik ders kitabı. Mega Yayınc1lık: Ankara.

Güven, B., Güç, F. A., \& Özmen, Z. M. (2016). Problem types used in math lessons: the relationship between student achievement and teacher preferences. International Journal of Mathematical Education in Science and Technology, 47(6), 863-876.

Hong, D. S.,\& Choi, K. M. (2014). A Comparison of Korean and American secondary school textbooks: The case of quadratic equations. Educational Studies in Mathematics, 85(2), 241-263.

Ibrahim, Z. B., \& Othman, K. I. (2010). Comparative Study of Secondary Mathematics Curriculum between Malaysia and Singapore. Procedia Social and Behavioral Sciences, 8, 351-355.

Işıksal, M., ve Çakıroğlu E. (2008). Preservice teachers knowledge of students cognitive processes about the division of fractions. Hacettepe University Journal of Education, 35, 175-185.

İymen, E., \& Paksu A. D. (2015). Analysis of 8th grade students' number sense related to the exponents in terms of number sense components. Education and Science, 40 (177), 109-125.

Kaput, J. J. (1987). Representation systems and mathematics. In C. Janvier (Ed.), Problems of representation in the teaching and learning of mathematics (pp.19-26). Hillsdale, NJ: Lawrence Erlbaum Associates.

Kar, T., Güler, G., Şen, C., ve Özdemir, E. (2018). Comparing the development of the multiplication of fractions in Turkish and American Textbooks. International Journal of Mathematical Education in Science and Technology, 49(2), 200-226.

Kheong, F. H., Soon, G. K., \& Ramakrishnan C. (2018). My Pals are here maths 6A (Pupil's Book), Mashall Cavendish Education: Singapore.

Kheong, F. H., Soon, G. K., \& Ramakrishnan C. (2018). My Pals are here maths 5A (Pupil's Book), Mashall Cavendish Education: Singapore.

Kilpatrick, J., Swafford, J., \& Findell, B. (Eds.). (2001). Adding it up: helping children learn mathematics. Washington, DC: National Academy Press.

Komisyon (2016). Ortaokul 6. Sınıf matematik ders kitabı. Milli Eğitim Bakanlığı Yayınları: Ankara.

Lee, K., \& Fong, N. S. (2009). Solving Algebra Word Problems: The Roles of Working Memory and the Model Method. In W. K. Yoong, L. P. Yee, B. Kaur, F. P. Yee, \& N. S. Fong (Eds.), Mathematics education: the Singapore journey (pp.169-203). World Scientific Publishing: Singapore.

Leung I. K. C., \& Carbone R. E. (2013). Pre-service teachers' knowledge about fraction division reflected through problem posing. The Mathematics Educator, 14(1-2): 80-92.

Li, Y., Chen, X., \& An, S. (2009). Conceptualizing and organizing content for teaching and learning in selected Chinese, Japanese and US mathematics textbooks: The case of fraction division. ZDM Mathematics Education, 41, 809-826.

Lin, C. Y., Becker, J., Byun, M. R., Yang, D. C., \& Huang, T. W. (2013). Preservice teachers' conceptual and procedural knowledge of fraction operations: A comparative study of the United States and Taiwan. School Science and Mathematics, 113(1), 41-51.

MOES (2012), Mathematics syllabus: primary one to five. https://www.moe.gov.sg/docs/defaultsource/document/education/syllabuses/sciences/files/primary_mathematics_syllabus_pri1_to_pri 5.pdf adresinden 04.04.2019 tarihinde alınmıştır. 
Mullis, I.V.S., Martin, M. O., Foy, P., \& Hooper, M. (2015). TIMSS 2015 International results in Mathematics, [Internet]. [cited 2017 Oct 18]. Available from http://timssandpirls.bc.edu/timss2015/internationalresults/

Özer, E., ve Sezer, R. A. (2014). Comparative analysis of questions in American, Singaporean, and Turkish mathematics textbooks based on the topics covered in 8th grade in Turkey. Educational Sciences: Theory and Practice, 14(1), 411-421.

Scouller, K. (1998). The influence of assessment method on students' learning approaches: Multiple choice question examination versus assignment essay. Higher Education, 35, 453-472.

Şengül, S., \& Gülbağcı H. (2015). An investigation of 5th grade Turkish students' performance in number sense on the topic of decimal numbers. Procedia Soc Behav Sci, 46, 2289-2293.

Siegler, R. P., Carpenter T., Fennell F., Geary D., Lewis J., Okamoto Y., Thompson L., \& Wray J. (2010). Developing effective fractions instruction for kindergarten through 8th grade (NCEE 2010-4039). Washington, DC: U.S. Department of Education, Institute of Education Sciences, National Center for Education Evaluation and Regional Assistance.

Silver, E. A. (1994). On mathematical problem posing. For the Learning of Mathematics, 14(1), 19-28.

Simon, M. A. (1993). Prospective elementary teachers' knowledge of division. Journal for Research in Mathematics Education, 24, 233-254.

Son, J. W., \& Senk, S. L. (2010). How reform curricula in the USA and Korea present multiplication and division of fractions. Educational Studies in Mathematics, 74 (2), 117-142.

Son, J. W. (2011). A global look at math instruction. Teaching Children Mathematics, 17(6), 360-368.

Son, J. W. (2012). A Cross-National comparison of reform curricula in Korea and the US in terms of cognitive complexity: the case of fraction addition and subtraction. ZDM Mathematics Education, 44 (2), 161-174.

Son, J. W., \& Hu, Q. (2016). The initial treatment of the concept of function in the selected secondary school mathematics textbooks in the US and China. International Journal of Mathematical Education in Science and Technology, 47(4), 505-530.

Stein, M. K., Remillard, J., \& Smith, M. S. (2007). How curriculum influences learning. İçinde F. Lester (Ed.), Second handbook of research on Mathematics teaching and learning (pp. 319-370). Charlotte, NC: Information Age.

Tall, D. (1988). Concept image and concept definition. In J de Lange \& M. Doorman (Eds.), Senior secondary Mathematics education (pp. 37-41). Utrecht:OW\&OC.

Tang, K.C.C. (1992). Perceptions of task demand, strategy attributions and student learning. Research and Development in Higher Education, 15, 474-481.

Tirosh, D. (2000). Enhancing prospective teacher' knowledge of children's conceptions: The case of division of fractions. Journal for Research in Mathematics Education, 31(1), 5-25.

Van de Walle, J. A., Karp K. S., \& Bay-Williams J. M. (2010). Elementary and middle school mathematics: Teaching developmentally (7th ed.). Boston: Allyn \& Bacon.

Vula, E., Kingji-Kastrati, J., \& Podvorica, F. (2015). A comparative analysis of mathematics textbooks from Kosovo and Albania based on the topic of fractions. In K. Krainer \& N. Vondrová (Eds). Proceedings of the Ninth Congress of the European Society for Research in Mathematics Education, CERME 9 (pp. 1759-1765). Czech Republic: Prague.

Yang, D. C. (2018). Study of fractions in elementary mathematics textbooks from Finland and Taiwan. Educational Studies, 44(2), 190-211.

Yang, D. C., Reys, R. E., \& Reys, B. J. (2009). Numbersense strategies used by pre-service teachers in Taiwan. International Journal of Science and Math-ematics Education,7, 383-403

Yang, D. C., Reys, R. E., \& Wu, L. L. (2010). Comparing how fractions were developed in textbooks used by the 5th- and 6th-graders in Singapore, Taiwan, and the U.S.A. School Science and Mathematics, 110(3), 118-127. 
Yang, D. C., \& Wu, W. R. (2010). The study of number sense realistic activities integrated into third grade math classes in Taiwan. The Journal of Educational Research. 103(6), 379-392.

Verschaffel, L., Greer, B., \& De Corte, E. (2007).Whole number concepts and operations. In F. LesterJr. (Ed.), Second handbook of research on math-ematics teaching and learning (pp. 557-628). Charlotte, NC: Information Age.

Viera, A. J., \& Garrett, J. M. (2005). Understanding interobserver agreement: The Kappa statistic. Family Medicine, 37(5), 360-363.

Wong, K. Y.,\& Lee, N. H. (2009). Singapore Education and Mathematics Curriculum. In W. K. Yoong, L. P. Yee, B. Kaur, F. P. Yee, \& N. S. Fong (Eds.), Mathematics education: the Singapore journey (pp.13-47). World Scientific Publishing: Singapore.

Zhu, Y., \& Fan L. (2006). Focus on the representation of problem types in intended curriculum: A comparison of selected mathematics textbooks from Mainland China and the United States. International Journal of Science and Mathematics Education, 4(4), 609-626. 


\section{Extended Abstract}

\section{Introduction}

International comparison studies are one of the most important indicators that reveal the success of countries in mathematics. It is known that some Far Eastern countries usually take the first places in these exams. In the Trends in International Mathematics and Science study in 2015, Singapore ranked 1st in mathematics with 621 points. Turkey, however, has shown a poor performance in international comparison studies in the field of mathematics. It is possible to explain the difference between the mathematics performances of Turkish and Singaporean students with many reasons. The textbooks teachers use as the main source in their courses can be considered as one of the reasons for the differences between the mathematics performances of students. Because textbooks used in a country reflect the educational philosophy of that country, and they determine what students learn, how they learn it and what teachers teach. In recent years, there has been an increase in the number of book comparison studies. In the studies, books were analyzed in terms of teaching content and problem type. The mathematics textbooks used in Turkey were compared with the textbooks of the countries in the top five in international examinations (only Singapore textbooks) in terms of design features and problem types. In this study where the Turkish and Singapore textbooks were compared in terms of problem type, the comparison was only made on the subjects included in the $8^{\text {th }}$ grade Turkish textbook. In this context, in the study, the Turkish and Singapore textbooks were compared in terms of problem types included in the subject, dividing fractions, which is one most students have difficulty in understanding.

\section{Method}

In this study, two Turkish and two Singapore books were examined. In Singapore, four mathematics textbooks are currently used at the primary education level. These textbooks are: My pals are here!, New Syllabus Primary Mathematics, Shaping Maths, Targeting Mathematics. In about $60 \%$ of the secondary schools in Singapore, the textbook named "My pals are here!" is used. In this study, the third edition of the textbook named "My pals are here!", which was published in 2018, was examined in terms of the subject of division of fractions. For the theoretical framework to be used in the analysis of the problems in the mathematics textbooks, studies in the literature have been used. The problems were categorized according to their characteristics of number of solution steps, type of answer, context and cognitive expectation. The analysis of the problems in the textbooks was done by two expert academicians. The Cohen Kappa agreement index between the codes was found between 0.98-1.00 for each category.

\section{Results and Discussion}

In this study, Turkish and Singapore textbooks were compared in terms of problem types in the subject of division of fractions, in which most students have difficulty understanding. Most problems in the textbooks are problems to be solved in one step and that require numerical expression. Compared to the Turkish textbooks, the Singapore textbooks have a greater number of problems that require multi-step calculation and explanation-solution and aim to test conceptual understanding. The problem types in the textbooks are reflected in the performances of students in international exams. Studies show that Chinese textbooks are richer than American textbooks in terms of questions that require multi-step solutions. In fact, The National 
Assessment of Educational Progress (NAEP) report shows that most American primary school students have difficulty in multi-step problems. Problems with incomplete or excessive data are not included in the books. The curriculum of mathematics aims to raise individuals with advanced problem solving skills. In activities aimed at developing problem solving skills, the four-stage problem-solving process defined by Polya is adopted. One of the expected indicators for these processes in the mathematics curriculum is to determine "whether the problem includes incomplete, excessive or adequate information". The number of verbal-daily life problems in textbooks is small. The researchers emphasized that real life problems will attract students' attention and increase their motivation to solve the problem. In addition, real life problems help students learn mathematics since they provide the opportunity to associate existing knowledge schemes with new information. In this respect, it is important to enrich the textbooks of the two countries with daily life problems with incomplete and excessive data. Another important finding obtained from the study is that the textbooks of the two countries do not include problem posing practices. Problem posing practices give students the opportunity to translate a mathematical expression given in symbolic or visual form into verbal form and reveal whether students learned mathematical concepts. In this respect, problem posing practices should be included in textbooks. In the Turkish books, there are few problems in the category of mathematical reasoning and representation compared to the Singapore books, and there is no problem in the Turkish books in the category of conceptual knowledge. Studies show that American students prefer to use visual representation more than Chinese students in problem solving as American textbooks include more problems presented in visual form compared to Chinese textbooks. In the Trends in International Mathematics and Science Study, three out of four of the mathematics questions were from cognitive fields of practice and reasoning. The questions in the practice category examine whether students conceptually learned the concepts and symbols within the question, and the questions in the reasoning category are open-ended and multi-step, and students are expected to use different solution strategies and explain their solutions. The findings can be considered as one of the reasons why Singaporean students perform better than Turkish students in terms of number content domain in international exams. In the light of the results obtained from the study, it can be presented as a recommendation that different types of problems should be distributed to the textbooks of both countries in a balanced way. Turkish textbooks in particular should be enriched in terms of problems in the categories of conceptual knowledge, mathematical reasoning and representation. In future studies, it can be investigated what kind of problems mathematics teachers use in their lessons. 